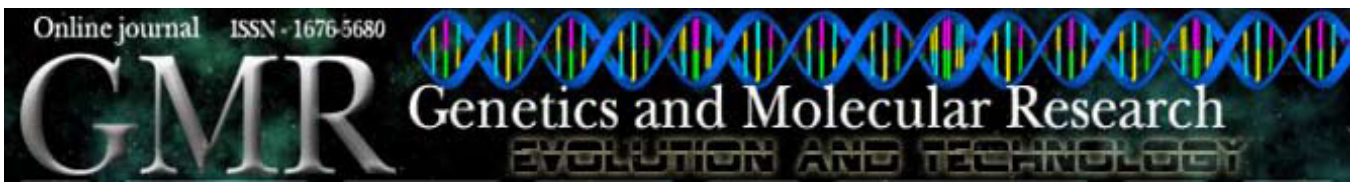

\title{
Intrinsic colony conditions affect the provisioning and oviposition process in the stingless bee Melipona scutellaris
}

\author{
R.A. Pereira ${ }^{1}$, M.M. Morais ${ }^{1}$, F.S. Nascimento ${ }^{2}$ and L.R. Bego ${ }^{1}$ \\ ${ }^{1}$ Departamento de Biologia, Faculdade de Filosofia, \\ Ciências e Letras de Ribeirão Preto, \\ Universidade de São Paulo, Ribeirão Preto, SP, Brasil \\ ${ }^{2}$ Departamento de Biologia, Centro de Ciências Biológicas e da Saúde, \\ Universidade Federal de Sergipe, São Cristóvão, SE, Brasil \\ Corresponding author: F.S. Nascimento \\ E-mail: fabio.nascimento@pesquisador.cnpq.br
}

Genet. Mol. Res. 8 (2): 725-729 (2009)

Received December 12, 2008

Accepted January 26, 2009

Published June 23, 2009

\begin{abstract}
The cell provisioning and oviposition process (POP) is a unique characteristic of stingless bees (Meliponini), in which coordinated interactions between workers and queen regulate the filling of brood cells with larval resources and subsequent egg laying. Environmental conditions seem to regulate reproduction in stingless bees; however, little is known about how the amount of food affects quantitative sequences of the process. We examined intrinsic variables by comparing three colonies in distinct conditions (strong, intermediate and weak state). We predicted that some of these variables are correlated with temporal events of POP in Melipona scutellaris colonies. The results demonstrated that the strong colony had shorter periods of POP.
\end{abstract}

Key words: Provisioning and oviposition process; Food storage; Stingless bees; Melipona 


\section{INTRODUCTION}

Stingless bees (Meliponini) are highly diverse and mass provisioning eusocial bees (Engels and Imperatriz-Fonseca, 1990). Brood cells are used once, when they are provisioned with larval food and an egg is laid; and most interactions between the queen and workers appear during the provisioning and oviposition process (POP; Sakagami, 1982). The POP involves i) construction of new brood cells by workers in a specific area of the nest; ii) provisioning of the cells with larval food by workers; iii) oviposition in the cells by the queen, and iv) sealing of the cells by workers.

Social interactions between castes occur mainly at the brood comb surface, where new cells are added; such interactions are part of the sociobiology of these bees (Crespi, 1992; Sommeijer and Bruijin, 1994). For example, genetic conflict on the brood comb involves physical conflict (Peters et al., 1999; Tóth et al., 2003), and the frequency of food discharges by workers in gyne-producing cells differs from that in worker-producing cells (van Veen, 2000). Early studies suggested that the structure of the POP is influenced by internal and external variables (Sakagami and Zucchi, 1974; Bego, 1990).

The amount of stored food is one of the main features that influences the development of stingless bee colonies. Ecological aspects, such as worker longevity, the reproductive cycle and brood rearing, are determined by pollen abundance and flower availability in the environment (Roubik, 1989; van Veen et al., 1992). However, little is known about how food supplies and other colony intrisic factors (e.g., queen age) affect POP parameters. Because of the diversity of patterns of POP observed among Meliponini species and even within a species (Zucchi, 1973; Zucchi et al., 1999), we decided to determine whether the typical POP behavioral features are influenced by internal conditions in colonies of Melipona scutellaris.

\section{MATERIAL AND METHODS}

Three colonies of M. scutellaris (henceforth 1, 2 and 4) were collected in Pilões, Paraíba State, Brazil, and transferred to the Departamento de Biologia, Universidade de São Paulo, Ribeirão Preto, São Paulo State, Brazil. We used amount of pollen and honey pots to classify internal conditions of colonies: colony 1 - weak conditions, colony 2 intermediate conditions, and colony 4 - strong conditions. In the laboratory, the colonies were maintained in wooden boxes covered by a glass plate to permit behavioral observations. Plastic tubes were connected between each box and the outside, allowing the bees to forage freely. To avoid the effects of transport and transference on the internal conditions of colonies, we initiated the observations after a month. The temperature inside the hives was kept between $26^{\circ}$ and $28^{\circ} \mathrm{C}$.

Quantitative aspects of POP from a total of 407 sequences were registered for six months (June to December 2001). We used as POP variables the interval between two consecutive POP, number of provisioned cells, number of trophic eggs laid during the process, duration of queen egg laying, and duration of cell capping. The number of workers on the brood during the processes was also counted.

We used a general linear model with MANOVA (multivariate GLM) to verify the influence of food storage (pollen and honey) on the POP parameters. Quantitative differ- 
ences among colonies were tested with the Kruskal-Wallis test or ANOVA concerning the normality requirements (Sokal and Rohlf, 1995). All statistical analyses were performed with the Statistica 6.0 program (StatSoft Inc.).

\section{RESULTS AND DISCUSSION}

POP parameters were significantly affected by intercolony differences (Table 1). POP varied significantly among colonies (period of operculation: $H=65.15, \mathrm{P}<0.001$; period of queen egg laying: $H=213.20, \mathrm{P}<0.001$; number of provisioned cells: $H=11.38, \mathrm{P}<0.01$; number of trophic eggs laid: $H=104.80, \mathrm{P}<0.001)$. Colonies also differed in their rate of POP sequences per day: colony 4 (21.3 $\pm 5.4 \mathrm{POPs} /$ day $)$, colony $2(12.7 \pm 5.9 \mathrm{POPs} /$ day $)$ and colony $1(5.8 \pm 3.2 \mathrm{POPs} /$ day $)$.

\begin{tabular}{|c|c|c|c|c|c|}
\hline Effect & Sum of squares & Degrees of freedom & Mean squared & $F$ & $P$ \\
\hline \multicolumn{6}{|l|}{ Provisioned cells per POP } \\
\hline Colony*Pollen*Honey & 740.82 & 2 & 370.41 & 13.731 & 0.0001 \\
\hline Error & 1132.96 & 42 & 26.98 & & \\
\hline \multicolumn{6}{|l|}{ Number of trophic eggs } \\
\hline Colony*Pollen*Honey & 1.44 & 2 & 0.72 & 0.863 & NS \\
\hline Error & 223.36 & 268 & 0.83 & & \\
\hline \multicolumn{6}{|l|}{ Capping time (s) } \\
\hline Colony*Pollen*Honey & 48.268 & 2 & 24.134 & 9.252 & 0.0001 \\
\hline Error & 732.98 & 281 & 2.608 & & \\
\hline \multicolumn{6}{|l|}{ Egg laying time (s) } \\
\hline Colony*Pollen*Honey & 35.3 & 2 & 17.7 & 0.819 & NS \\
\hline Error & 5603.2 & 260 & 21.6 & & \\
\hline
\end{tabular}

Colony 4 exhibited shorter periods of POP than the other two colonies (Figure 1A-C). Colonies 2 and 4 varied only in relation to queen oviposition duration and interval between two consecutive POP processes (Figure 1B,C). We found that colony size and amount of food stored affect POP in M. scutellaris; they are probably also key factors in other stingless bee species (Sakagami and Zucchi, 1967; Camillo-Atique, 1974).

General linear models showed that the cell sealing and queen egg laying times were significantly affected by intracolony conditions and food storage (Table 1). The average number of trophic eggs did not vary between colonies (Figure 1D: (means \pm SD) colony 1: $1.24 \pm$ 1.23 eggs/process; colony 2: $1.22 \pm 0.93$ eggs/process; colony $4: 1.19 \pm 0.93$ eggs/process; $F$ $=0.89 ; \mathrm{P}=0.91 ;$ ANOVA). This suggests that some parameters are affected by other factors, such as age or food intake.

Food storage (pots of honey and pollen) had a significant effect on capping duration and the number of provisioned cells per process, but had no influence on the time of queen oviposition (Table 1). Previous studies revealed that the population size of a colony affects sexual production in Melipona bees (van Veen et al., 1999). In M. beecheii, food manipulation 

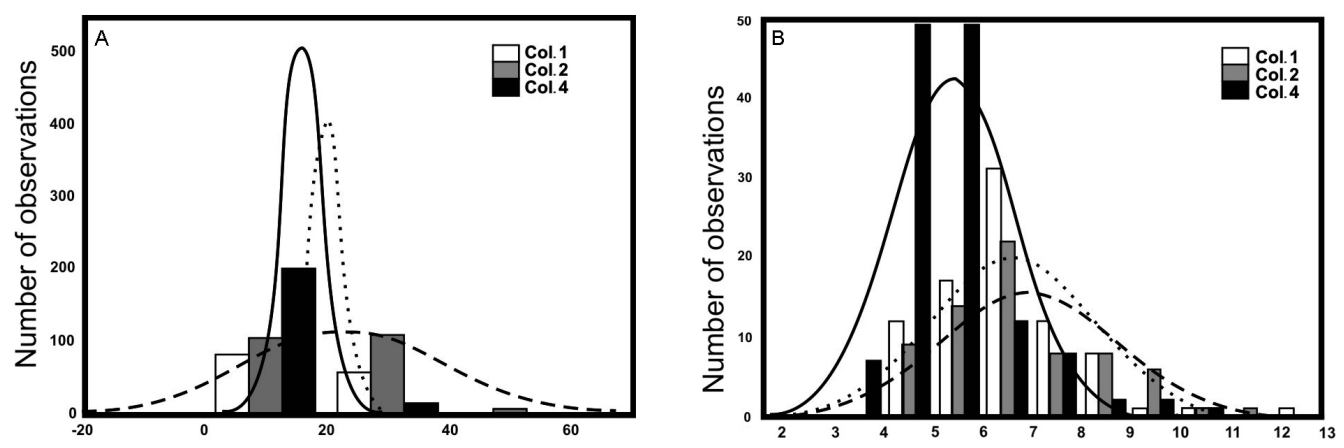

Time (s)
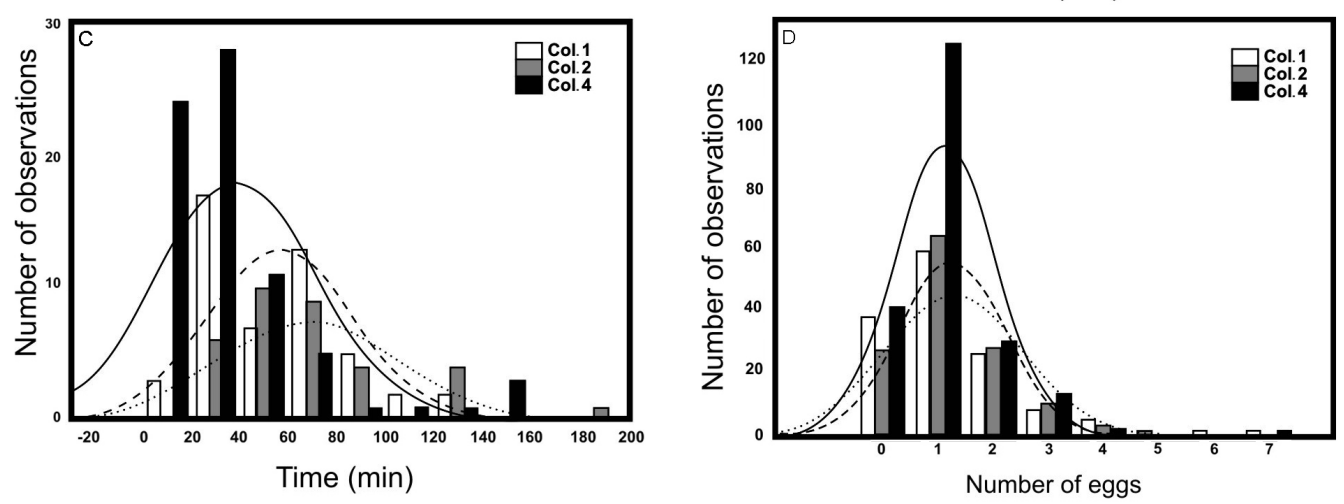

Figure 1. Patterns of cell provisioning and oviposition in Melipona scutellaris. A. Time of capping (Colony (Col.) 1 x Col. 2: NS; Col. 1 x Col. 4: $Z=-6.45 ; P<0.001 ;$ Col. 2 x Col. $4: Z=-6.74 ; P<0.001$. B. Period of queen oviposition (Col. 1 x Col. 2: $Z=-7.39 ; P<0.0001$; Col. $1 \times$ Col. 4: $Z=-11.39 ; P<0.0001$; Col. $2 \times$ Col. 4: $Z=$ -13.37; P < 0.0001). C. Interval between two consecutive processes (Col. 1 x Col. 2: NS; Col. 1 x Col. 4: Z= -4.09; $\mathrm{P}<0.001$; Col. $2 \times$ Col. 4: $\mathrm{Z}=-4.76 ; \mathrm{P}<0.001)$. D. Number of trophic eggs laid by workers (Col. 1 x Col. 2 : NS; Col. 1 x Col. 4: NS; Col. 2 x Col. 4: NS).

experiments showed that although food-deprived colonies have decreased production of offspring, intercolony differences strongly influence colony production (Moo-Valle et al., 2001). In a previous study, Morais et al. (2006) found that food storage regulated male and worker production, but not gyne production.

Sommeijer and Bruijin (1994) stated that the complex ritualized behaviors between the queen and workers of $M$. favosa involved communication during the characteristic system of larval feeding. Sakagami discriminated POP in a number of phases and subphases (reviewed in Sakagami, 1982): provisioning phase, oviposition phase and capping phase. In the current study, we demonstrated that several aspects of these subphases are linked with food storage in M. scutellaris colonies.

\section{ACKNOWLEDGMENTS}

The authors are grateful to Dr. Sidnei Mateus for his technical advice. Research supported by the Fundação de Amparo à Pesquisa do Estado de São Paulo (FAPESP) and by the 
Coordenação de Aperfeiçoamento de Pessoal de Nível Superior (CAPES). This study is dedicated to Prof. Dr. Warwick E. Kerr for his devoted life to the stingless bees.

\section{REFERENCES}

Bego LR (1990). On social regulation in Nannotrigona (Scaptotrigona) postica Latreille, with special reference to productivity of colonies (Hymenoptera, Apidae, Meliponinae). Rev. Bras. Entomol. 34: 721-738.

Camillo-Atique C (1974). Variabilidade do Comportamento de Melipona rufiventris rufiventris (Hymenoptera, Apoidea). Master’s thesis, Faculdade de Medicina de Ribeirão Preto, Universidade de São Paulo, Ribeirão Preto.

Crespi BJ (1992). Cannibalism and Trophic Eggs in Subsocial and Eusocial Insects. In: Cannibalism: Ecological and Evolutionary Implications (Elgar MA and Crespi BJ, eds.). Oxford University Press, Oxford, 176-213.

Engels W and Imperatriz-Fonseca VL (1990). Caste Development, Reproductive Strategies, and Control of Fertility in Honey Bees and Stingless Bees. In: Social Insects: An Evolutionary Approach to Castes and Reproduction (Engels W, ed.). Springer-Verlag, Berlin, 167-230.

Moo-Valle H, Quezada-Euán JJG and Wenseleers T (2001). The effect of food reserves on the production of sexual offspring in the stingless bee Melipona beecheii (Apidae, Meliponini). Insectes Soc. 48: 398-403.

Morais MM, Nascimento FS, Pereira RA and Bego LR (2006). Colony internal conditions related to caste production in Melipona compressipes fasciculata (Hymenoptera: Apinae, Meliponini). Insectes Soc. 53: 265-268.

Peters JM, Queller DC, Imperatriz-Fonseca VL, Roubik DW, et al. (1999). Mate number, kin selection and social conflicts in stingless bees and honeybees. Proc. R. Soc. Lond. B 22: 379-384.

Roubik DW (1989). Ecology and Natural History of Tropical Bees. Cambridge University Press, Cambridge.

Sakagami SF (1982). Stingless Bees. In: Social Insects (Hermann HR, ed.). Vol. 3. Academic Press, New York, 361-423.

Sakagami SF and Zucchi R (1967). Behavior studies of the stingless bees, with special reference to the oviposition process. VI. Trigona (Tetragona) clavipes. J. Fac. Sci. Hokkaido Univ. Ser. 6 Zool. 16: 292-313.

Sakagami SF and Zucchi R (1974). Oviposition behavior of two dwarf stingless bees, Hypotrigona (Leurotrigona) muelleri and H. (Trigonisca) duckei, with notes on the temporal articulation of oviposition process in stingless bees. J. Fac. Sci. Hokkaido Univ. Ser. 6 Zool. 19: 361-421.

Sokal RR and Rohlf FJ (1995). Biometry. 3rd edn. W.H. Freeman, New York.

Sommeijer MJ and Bruijn LLM (1994). Intranidal Feeding, Trophallaxis, and Sociality in Stingless Bees. In: Nourishment and Evolution in Insect Societies (Hunt JH and Nalepa CA, eds.). Westview Press, Oxford, 391-418.

Tóth E, Strassmann JE, Imperatriz-Fonseca VL and Queller DC (2003). Queens, not workers, produce the males in the stingless bee Schwarziana quadripunctata quadripunctata. Anim. Behav. 66: 359-368.

van Veen JW (2000). Cell provisioning and oviposition in Melipona beecheii (Apidae, Meliponinae), with a note on caste determination. Apidologie 31: 411-419.

van Veen JW, Arce H and Sommeijer MJ (1992). Brood Production of Melipona beecheii in Relation to Dry Season Foraging. In: Biology and Evolution of Social Insects (Billen J, ed.). Leuven University Press, Leuven, 81-87.

van Veen JW, Sommeijer MJ and Arce H (1999). The Role of Colony Development and Resource Availability in the Regulation of Queen Production in Melipona beecheii (Apidae, Meliponini). In: Colony Reproduction in Stingless Bees (van Veen JW, ed.). Utrecht University Litografia Imprenta Lil S.A., San José, 80-87.

Zucchi R (1973). Aspectos Bionômicos de Exomalopsis aureopilosa e Bombus atratus Incluindo Considerações sobre o Comportamento Social (Hymenoptera, Apoidea). Doctoral thesis, Faculdade de Filosofia Ciências e Letras de Ribeirão Preto, Universidade de São Paulo, Ribeirão Preto.

Zucchi R, Silva-Matos EV, Nogueira-Ferreira FH and Azevedo GG (1999). On the cell provisioning and oviposition process (POP) of the stingless bess - nomenclature reappraisal and evolutionary considerations (Hymenoptera, Apidae, Meliponinae). Sociobiology 34: 65-86. 